\title{
Forum
}

\section{The possibility of common ground: a reply to Mavhunga and Robinson}

\author{
Sonja Vermeulen and Douglas Sheil
}

In our article (Vermeulen \& Sheil, 2007) we encouraged stronger partnerships between conservation interests and local people. Such partnerships are often more ethical, and potentially more effective, than alternative conservation models. We did not argue that such partnerships are simple, guarantee success or will address all other concerns, but effective partnerships can reduce conflicts, which are a constraint to progress in tropical conservation. Clapperton Mavhunga (2007) and John Robinson (2007) develop contrasting perspectives, often moving beyond the scope of our article. Here we address some points and encourage readers to judge the rest. Both commentators emphasize their disagreements but both offer arguments that bolster rather than weaken our own.

Both commentators find problems in our abstract. Robinson dislikes our premise that global conservation is largely '... devised and controlled by a small group of powerful, external voices'. This he suggests '. . .does not forward [our] analysis'. Nonetheless he avoids engaging with the charge and the implications of the democratic deficit it entails. Who does, could and should conservation serve? Coming from the opposite perspective, Mavhunga, '....in the trenches fighting...', castigates our encouragement for conservationists to give local people 'the opportunity' for deeper involvement. His analysis, and creative use of italics, reveals our eagerness to exploit local people. He calls partnerships passé but fails to explain why. We wish Mavhunga well in mobilizing his 'global coalitions against poverty', his 'new democracies of knowledge' and his 'answer to global warming'. But it may take a while. In the meantime stopgap measures, such as partnerships, can be helpful.

Robinson accepts our conclusion regarding the value of partnerships but he finds other points of departure. He quotes from various large US-based NGOs to show that partnerships are nothing new. But we do not make any

Sonja Vermeulen International Institute for Environment and Development, 3 Endsleigh Street, London, WC1H ODD, UK.

Douglas Sheil (Corresponding author) Center for International Forestry Research, P.O. BOX 6596, JKPWB, Jakarta 10065, Indonesia. E-mail d.sheil@cgiar.org

Received 13 October 2007. Accepted 14 October 2007. claim to novelty, our own examples span decades. Our point is that deeds often fail to match up to the rhetoric.

We agree with Robinson that partnership is not easy and that there are significant challenges in linking the differing views and needs of local residents and international conservation agencies. His commentary provides a valuable addition to ours by providing further detail on institutional challenges and solutions, with several useful contemporary examples. Our commentary made many related points on tactics, rules, checks and balances, accountability, and negotiated trade-offs. This is not defining away differences. Indeed, in our section entitled Recognize costs and trade-offs we went further than Robinson by recognizing the differences within communities in perceptions and in incentives for engagement. For the interested practitioner there is now an abundance of literature to guide collaborative conservation (e.g. Borrini-Feyerabend et al., 2004, and references within).

The issue perhaps for Robinson is why we use the normative term 'partnership' rather than a more 'cleareyed' neutral alternative such as relationship, association, arrangement, deal or transaction. We characterize partnership as resting on equitable sharing of decisions, rights, responsibilities and risks. Is such a model realistic?

We don't know many conservationists who need to have the differences between themselves and other stakeholders, or roles and motivation, spelt out for them. If we observed numerous conservationists naïvely assuming common ground with each and every local person they came across, or even if we felt it was a possibility, Robinson's 'clear-eyed' caution would be warranted. But the more common problem is the reverse: many conservationists assume that finding common ground is impossible or a recipe for disappointment.

We need to be clear here that we are not advocating a one size fits all approach. We would not even go as far as asserting a set of good practices. What is important is the spirit of the relationship. This is why we emphasize application of high standards: aspiring to equitable partnership even if this goal is lofty. Good practice may not be transferable but good principle is. Aspiration towards partnership can shape a mutually respectful relationship that is more likely to deliver the different benefits each side seeks. 
As Robinson notes, there may be complex networks of stakeholders and institutions in any major conservation work. We disagree that this invalidates the utility of oneon-one partnerships. Certainly, cooperation and coordination among many different groups can and do happen to bring about conservation. In other cases it is of advantage to local communities to make tactical alliances with conservation bodies, be they local or national, to defend their land rights, resource access and cultural identity against other stakeholders seeking alternatives such as large-scale mining or plantation development. Perhaps even more challenging than partnership between conservationists and local residents is how best to negotiate and reach consensus with industry and other powerful external interests.

This brings us back to Mavhunga's commentary. For Mavhunga the primary issue is whether external conservation agencies should be present at all. This is a good question. Should it be conservation agencies '... [giving] the opportunity' to local people to participate in conservation, or should local people be giving the opportunity to conservation agencies to participate in local land management? In reality, of course, a wider set of social groups hold a stake. Our own conclusions express the ideal that '... natural resource governance should be legitimate and subject to democratic control; conservation's costs and benefits should be distributed equitably'. In exploring the legitimacy of conservation Mavhunga segues seamlessly from his commentary on communities into his narrative on Africa without noting any distinctions. But it is precisely because there is no unified African interest that strategic allegiances between local people and conservationists offer real benefits, such as defending lands from destructive development.

Regarding Mavhunga's assertion that we fail to imagine locally conceived conservation, we refer him and other readers to our table (Vermeulen \& Sheil, 2007) that specifically highlights the neglected potential of local practice and the more than 30 references that consider the wider political, economic and historical contexts of local practice. Mavhunga concludes his commentary with a call for open-minded, humble, multidisciplinary approaches receptive to local views. We agree. But Mavhunga seems unaware that such attempts are being made: our article cites examples (e.g. Shanley \& Gaia, 2002) and there are more (e.g. Sassen \& Jum, 2006).

Like Mavhunga we see local people as active players; unlike Mavhunga we don't see them exclusively or necessarily as history's victims. In many places local injustices still occur, often a result of extractive industries and weak regulation. As we acknowledge, rural people may well be disadvantaged, with less access to resources, services and decision-making than urban elites. But this does not mean they are powerless. As Mavhunga shrewdly notes, local people can 'play along' with conservation projects for as long as there are advantages, and can then 'carry on with their lives'. As such, conservation partnerships are not one-sided: both parties have the power to contribute or to withhold, and are likely to wield this power most effectively when commonalities rather than conflicts are emphasized.

Ultimately we find few substantive differences with either Mavhunga or Robinson. Conservation, development and social justice are major aspirations for large numbers of people. Individual and societal differences matter but shared visions are a stronger basis for action. We propose that for both conservationists and local people the search for common ground is often a search worth making.

\section{References}

Borrini-Feyerabend, G., Pimbert, M., Farvar, T., Kothari, A. \& Renard, Y. (2004) Sharing Power: Learning by Doing in Co-management of Natural Resources throughout the World. IIED and IUCN/CEESP/CMWG, Cenesta, Tehran, Iran.

Koziell, I. \& Inoue, C.Y.A. (2006) Mamirauá Sustainable Development Reserve, Brazil: Lessons Learnt in Integrating Conservation with Poverty Reduction. Biodiversity and Livelihoods Issues no. 7. International Institute for Environment and Development, London, UK.

Mavhunga, C. (2007) Even the rider and a horse are a partnership: a response to Vermeulen \& Sheil. Oryx, 41, 441-442.

Robinson, J. (2007) Recognizing differences and establishing clear-eyed partnerships: a response to Vermeulen \& Sheil. Oryx, 41, 443-444.

Robinson, J.G. \& Redford, K.H. (2004) Jack of all trades, master of none: inherent contradictions among ICD approaches. In Getting Biodiversity Projects to Work: Towards More Effective Conservation and Development (eds T.O. McShane \& M.P. Wells), pp. 10-34. Columbia University Press, New York, USA.

Sassen, M. \& Jum, C. (2007) Assessing local perspectives in a forested landscape in central Cameroon. Forest, Trees and Livelihoods, 17, 23-42.

Shanley, P. \& Gaia, G.R. (2002) Equitable ecology: collaborative learning for local benefit in Amazonia. Agricultural Systems, 73, 83-97.

Vermeulen, S. \& Sheil, D. (2007) Partnerships for tropical conservation. Oryx, 41, 434-440. 